\title{
AN ESTIMATION OF THE EFFECTS OF BREXIT ON TRADE AND MIGRATION
}

Rodolfo Campos and Jacopo Jimini

Documentos ocasionales

N. 1912

\section{BANCODE ESPANAA}

Eurosistema
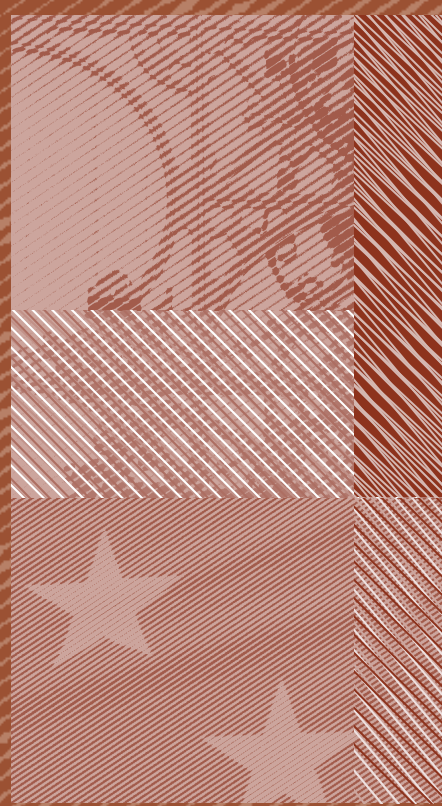
AN ESTIMATION OF THE EFFECTS OF BREXIT

ON TRADE AND MIGRATION ${ }^{(*)}$

Rodolfo Campos and Jacopo Timini

BANCO DE ESPAÑA

$\left(^{\star}\right)$ The views expressed in this manuscript are those of the authors and do not necessarily represent the views of

the Banco de España or the Eurosystem. We would like to thank Pilar L'Hotellerie, Pedro del Río and Juan Carlos Berganza for their comments and suggestions. All remaining errors are ours.

Documentos Ocasionales. N. ${ }^{\circ} 1912$

2019 
The Occasional Paper Series seeks to disseminate work conducted at the Banco de España, in the performance of its functions, that may be of general interest.

The opinions and analyses in the Occasional Paper Series are the responsibility of the authors and, therefore, do not necessarily coincide with those of the Banco de España or the Eurosystem.

The Banco de España disseminates its main reports and most of its publications via the Internet on its website at: http://www.bde.es.

Reproduction for educational and non-commercial purposes is permitted provided that the source is acknowledged.

C BANCO DE ESPAÑA, Madrid, 2019

ISSN: 1696-2230 (on-line edition) 


\section{Abstract}

This paper uses a gravity model approach to estimate the effects of Brexit in two dimensions: trade in goods and migration. We simulate two scenarios: 1) no agreement with reversion to WTO rules and no special treatment for migrants; 2) signature of a bilateral free trade agreement (FTA). According to our results, Brexit may have large negative effects on trade and migration flows between the EU and the UK. In the WTO scenario, trade flows are predicted to drop by $30 \%$ and migration by close to $25 \%$. If the UK and the EU sign an FTA-like agreement (which does not include free mobility of labour), the negative effects on trade are lessened although there is no significant difference in terms of migration with respect to the WTO scenario.

Keywords: international trade, migration, Brexit, gravity models, United Kingdom, European Union.

JEL classification: F13, F14, F17, F22. 


\section{Resumen}

Este documento utiliza un modelo de gravedad para estimar los efectos del brexit en dos dimensiones: el comercio de bienes y la migración. Simulamos dos escenarios: 1) no acuerdo, con reversión a las reglas de la OMC y sin trato especial para los migrantes; 2) firma de un acuerdo bilateral de libre comercio (TLC). Según nuestros resultados, el brexit puede tener efectos negativos importantes sobre el comercio y los flujos migratorios entre la UE y el Reino Unido. En el escenario de la OMC, se prevé que los flujos comerciales disminuyan en un $30 \%$ y la migración en cerca de un $25 \%$. Si el Reino Unido y la UE firman un acuerdo similar a un TLC (que no incluye la libre movilidad de la mano de obra), los efectos negativos sobre el comercio se reducen, aunque no hay una diferencia significativa en términos de migraciones con respecto al escenario de la OMC.

Palabras clave: comercio internacional, migración, brexit, modelos de gravedad, Reino Unido, Unión Europea.

Códigos JEL: F13, F14, F17, F22. 
INDEX

Abstract 5

Resumen 6

1 Introduction 8

2 Literature review 10

3 Methodology and scenarios 12

4 Data 14

5 Results 15

6 Conclusions 16

Appendix 17

References 18 


\section{Introduction}

"Should the United Kingdom remain a member of the European Union or leave the European Union?" This was the question printed on the ballots of the referendum held in the United Kingdom (UK) on 23 June 2016. With a 72\% turnout, almost 52\% of the voters declared their intention to leave the European Union (EU). Consequently, the British government triggered Article 50 of the Treaty on the European Union - that regulating the withdrawal from the Union on 29 March 2017, opening the two-year window ${ }^{1}$ for reaching an agreement between the EU and the UK.

The process of European economic integration has been extremely complex and very comprehensive in scope. This is shown by the depth of the acquis communautaire, i.e. the legal order of the EU, ${ }^{2}$ and, in particular, by the Single Market $^{3}$ and its potential for shaping the EU economy. The UK's exit from the EU, namely "Brexit", is set to revert and (at least partially) undo this course. This is likely to have profound implications for a variety of economic dimensions, in Europe and beyond, as the extensive nature of UK-EU relations multiplies the potential transmission channels of such an event. However, there are four channels of transmission of economic fragmentation that can be singled out: trade of goods and services (including financial services), migration, foreign direct investment (FDI) and, ultimately, productivity. ${ }^{4}$

This paper uses a gravity model approach to estimate the effects of Brexit for two of these dimensions: trade in goods and migration. Following Pisani and Vergara Caffarelli (2018), 5 we initially consider two alternative post-Brexit scenarios, assuming different degrees of disintegration. In the first, the UK and the EU do not reach any substantial agreement; therefore bilateral trade flows revert to WTO rules and migrants from both areas change to a situation of no special treatment. In the second scenario, the UK and the EU sign a bilateral free trade agreement (an FTA), which may entail effects for both trade and migration (see i.a. Glick, 2017; Orefice, 2015). In a gravity framework for trade and migration, the scenario where the UK becomes a member of the European Economic Area (EEA), ${ }^{6}$

1 The European Council "in agreement with the Member State concerned" (art.50, TEU) extended the window until 31 October 2019 (the window may end before that date if an agreement is reached).

2 As an indicator of its comprehensiveness, the European Commission, enumerating the "conditions for membership", summarises the acquis in 35 chapters: free movement of goods; freedom of movement for workers; right of establishment and freedom to provide services; free movement of capital; public procurement; company law; intellectual property law, competition policy, financial services; information society and media; agriculture and rural development; food safety, veterinary and phytosanitary policy; fisheries; transport policy; energy; taxation; economic and monetary policy; statistics; social policy and employment; trans-European networks; regional policy and coordination of structural instruments; judiciary and fundamental rights; justice, freedom and security; science and research; education and culture; environment; consumer and health protection; customs union; external relations; foreign, security and defence policy; financial control; financial and budgetary provisions; institutions; other issues.

3 The expression "Single Market" is used to refer to the internal market of the EU, which in the EU legislation is defined as "a single market in which the free movement of goods, services, capital and persons is assured, and in which citizens are free to live, work, study and do business" (EUR-Lex, 2018).

4 The productivity channel includes a variety of possible drivers, among them changes in trade (Alvarez and Lopez, 2008; Cortinovis and Timini, 2018); FDI (Cortinovis and van Oort, 2018), competition, R\&D, managerial skills (Mion et al., 2016).

5 They start from the pre-Brexit British Foreign and Commonwealth Office alternatives to the EU membership.

6 The EEA created an internal market for the EU member states and three (out of four) members of the European Free Trade Association (Iceland, Liechtenstein and Norway). The EEA internal market is driven by the same pillars of the EU Single Market (see note 3). The European Free Trade Association (EFTA) is a regional trade agreement whose current members are Iceland, Liechtenstein, Norway and Switzerland. 
maintaining full access to the Single Market and its "four freedoms" (free movement of goods, services, capital and persons) boils down to a "no-policy change" in relation to EU membership, i.e. a continuation of the status quo. This scenario will be our baseline. Therefore our analysis focuses on the first two alternative scenarios: the WTO scenario and the FTA scenario.

According to our results, Brexit may have large negative effects on trade and migration flows between the EU and the UK. In the WTO scenario, trade flows are predicted to drop by $30 \%$ and migration by close to $25 \%$. If the UK and the EU sign an FTA-like agreement (which does not include free mobility of labour), the negative effects on trade are lessened although there is no significant difference in terms of migration with respect to the WTO scenario.

The rest of the paper is organised as follows. Section 2 summarises the related literature, devoting particular attention to the application of gravity models for estimating trade and migration effects of any kind of trade (or currency) agreements, and their potential use to simulate trade disintegration (and Brexit in particular). Section 3 defines the main features of the models used in this paper. Section 4 briefly describes the data used. Section 5 discusses the results obtained and Section 6 concludes. 


\section{Literature review}

Gravity models have a long-established tradition in social sciences, at least since the 19th century (Anderson, 2011). They became the "workhorse" model used in research on trade and migration with Tinbergen's contribution (1962). As far as trade is concerned, gravity models have been used to respond to a variety of questions, from the nexus between trade and democracy (Yu, 2010) to the effects of trade on the environment (Frankel and Rose, 2005). The strand of the literature devoted to analysing the effects of trade agreements (TAs) and currency unions (CUs) on trade flows is the most relevant one for the purpose of this paper. The pioneering studies by Frankel (1997) and Rose (2000) provided early estimations of the significance of TAs and CUs for bilateral trade flows. The magnitude of the effects triggered a long debate, summarised by Carrère (2006) and Baldwin and Taglioni (2006), and stimulated the development of new estimation techniques to control for issues related to omitted variables bias, model mis-specification and endogeneity (Anderson and van Wincoop, 2003; Baier and Bergstrand, 2007; Head and Mayer, 2014; UNCTAD and WTO, 2016), mainly relying on different blends between country and time fixed effects.

Since the work by Baier and Bergstrand (2007) supporting the idea that TAs increase members' openness to international trade, there have been different studies focusing on the consequences of specific TAs: the NAFTA (Romalis, 2007; Caliendo and Parro, 2015); the Eastern Partnership Countries (Gylfason and Martinez-Zarzoso, 2015); the MENA region (Parra et al., 2016); MERCOSUR (Cuenca Garcia et al., 2013; Nowak-Lehmann and Martinez-Zarzoso, 2005); the ASEAN-China FTA (Yang and Martinez-Zarzoso, 2014; Yu et al., 2014); and the South Asian Free Trade Agreement (Islam et al., 2014). Cipollina and Salvatici (2010) summarise a major part of this literature with meta-analysis techniques. ${ }^{7}$

On the determinants of international migration, recent research employing gravity estimations on bilateral country data includes Grogger and Hanson (2011), Beine, Docquier, and Özden (2011), and Bertoli and Fernández-Huertas Moraga (2013). Ortega and Peri (2013) show that migration is highly responsive to income per-capita differentials across countries and that this elasticity is particularly high within the EU. Orefice (2015) and Figueiredo, Lima, and Orefice (2016), apply the gravitational framework to study the impact of TAs on migration.

Turning to Brexit, the potential of this event to revert the secular trend of integration among EU countries acted as a catalyst for many researchers, producing a proliferation of studies trying to assess the "costs-of-non-Europe" (Mayer et al., 2019). Most of the studies report considerable economic costs from Brexit, measured in terms of output or income, ranging between $-1 \%$ and $-10 \%$, approximately. The wide range of estimates is due to the diversity of scenarios assumed and of the channels considered (trade, migration, FDI, productivity, etc.)

7 The relative abundance of studies focussing on economic integration - rather than disintegration - episodes is dictated by the favourable historical trend since the second half of the $20^{\text {th }}$ century. To analyse economic fragmentation episodes, researchers often use data from the inter-war (e.g. de Bromehead et al., 2017) or the first globalisation (e.g. Timini, 2018) periods. 
(Bisciari, 2019). Dhingra et al. (2017) implement a general equilibrium trade model, following Ottaviano (2014), highlighting that the losses deriving from trade will affect both the EU and the UK, and will be significantly linked to the productivity channel. Along these same lines, Pisani and Vergara Caffarelli (2018) simulate different scenarios within a dynamic general equilibrium framework, finding that whereas in most cases the impact on the UK economy is non-negligible, the effects on the euro area economies are "negative, but quite limited". Kierzenkowski et al. (2016) consider both short and long-term channels of transmission to calibrate and simulate the size of the different Brexit scenarios using the National Institute Global Econometric Model (NiGEM). The HM Treasury (2016), the House of Commons Treasury Committee (2018) and the Bank of England (2018) also published their assessments on the Brexit effects. These three studies are very heterogeneous, both in terms of scenarios and methodology, but they coincide in indicating strong negative effects for the UK economy. Finally, the IMF (2018) used a standard computable general equilibrium model and a range of assumptions on the relative magnitude of the different Brexit transmission channels to find that the level of output is expected to decline by between 2 and $8 \%$.

Mayer et al. (2019) calculate the Brexit effects on trade, through the use of gravity equations, in a similar fashion to what we implement in this paper, but they do not include migration in their empirical analysis. Additionally, Mulabdic et al. (2017) use a partial equilibrium gravity model to estimate the Brexit effects on trade, finding a reduction in trade flows between $-6 \%$ and $-28 \%$, depending on the scenario considered. These numbers are largely in line with our estimations. Coupling two different strands of research (trade and migration) that previously remained separate in the literature analysing Brexit, we aim to provide a (more) comprehensive assessment and estimates of the Brexit effects on the international economy, with a particular focus on trade and migration. 


\section{Methodology and scenarios}

In the spirit of Head and Mayer (2014) and UNCTAD-WTO (2016), we implement a structural gravity model to assess the effects of Brexit on trade and migration. It is important to note that the existing data only allow us to estimate the effects of the UK entering the EU. So we have to assume that these effects are perfectly symmetric, i.e. that the effects derived from the EU accession are equal in size and opposite in sign to the effects of leaving the EU. Glick and Rose (2016) tested this hypothesis for trade in the case of entry and exit in monetary unions and found this assumption to be reasonable. However, the debate among economists is still open in the case of trade: some argue that the estimates for entry may be interpreted as a lower bound of the estimates for exit, as European value chains created since the UK accession would depend on strong comparative advantages and would have implied long-term investments, which are more difficult to destroy than to create; others argue that the estimates for entry may be interpreted as an upper bound for exit, as the interruption of the relevant international relations may occur abruptly with respect to how these relationships were forged. For example, the UK may not be able to replace all the TAs it is part of, due to its status as an EU member, or it might replace them with agreements with less favourable conditions, as its bargaining power (often related to market size) might decrease. In addition, these estimates do not incorporate dynamic effects through other channels, e.g., productivity, which may be significant (Dhingra et al., 2017).

Our estimation strategy develops in three steps. The first step consists in calculating an augmented gravity model (Anderson and van Wincoop, 2003). In the case of trade, our main equation is specified as follows:

$$
X_{i j t}=\exp \left(\beta_{0}+\beta_{1} E_{i j t}+\beta_{2} E U U K_{i j t}+\beta_{3} E_{u r o}{ }_{i j t}+\beta_{4} F A_{i j t}+\gamma_{i t}+\delta_{j t}+\eta_{i j}\right)+\epsilon_{i j t}
$$

where $\mathrm{X}_{\mathrm{ijt}}$ denotes export flows between the country of origin "i" (i.e. exporter) and the country of destination "j" (i.e. importer) at time t; ${ }^{8} \mathrm{EU}_{\mathrm{ijt}}$ is a dummy which takes value 1 when both countries are EU members at time t, but neither of them is the UK; EUUK $\mathrm{Jit}_{\mathrm{jt}}$ is a dummy, which is equal to 1 when both countries are EU members and one of them is the UK; Euro ijt is a dummy which takes value 1 when both countries are Euro-area members; FTA is a dummy that identifies country pairs which have a trade agreement in place; $\gamma_{\text {it }}$ and $\delta_{\text {jt }}$ are exporter-time and importer-time fixed effects and are included to account for multilateral resistances (Anderson and van Wincoop, 2003; Feenstra, 2016); $\eta_{i j}$ are country-pair fixed effects, and are included to control for potential endogeneity of the dummy variables included in the regression (Baier and Bergstrand, 2007). We include not only international but also internal trade flows, to minimise possible biases in estimating the "globalisation effects" (see Yotov, 2012). Finally, following Anderson and Yotov (2016), we assume that trade policy-related adjustment does not happen instantaneously and we use 4 -year intervals. ${ }^{9}$

8 Technically, with Poisson Pseudo-Maximum Likelihood (PPML), flows of any of our variables of interest are inserted in levels. However, the interpretation is equivalent to the logarithm of flows in an OLS model.

9 Estimates are robust to the use of the usual 1-year time interval. 
In the case of migration, the main differences consist in the separation between migration inflows and outflows, and in the introduction of additional details on trade agreements.

$$
\begin{aligned}
\mathrm{M}_{\mathrm{ijt}}= & \exp \left(\beta_{0}+\beta_{1} \mathrm{EUmov}_{\mathrm{ijt}}+\beta_{2} \mathrm{EUmovUKin}_{\mathrm{ijt}}+\beta_{3} \text { EUmovUKout }_{\mathrm{ijt}}+\beta_{4} \mathrm{CU}_{\mathrm{ijt}}+\beta_{5} \mathrm{EIA}_{\mathrm{ijt}}+\beta_{6} \mathrm{FTA}_{\mathrm{ijt}}+\gamma_{\mathrm{it}}\right. \\
& \left.+\delta_{\mathrm{jt}}+\eta_{\mathrm{ij}}\right)+\epsilon_{\mathrm{ijt}}
\end{aligned}
$$

The variable $M_{i j t}$ stands for bilateral migration flows from country $i$ to $j$. The variable $E U_{m o v} v_{i j t}$, takes the value 1 if there is free mobility between EU country $i$ and EU country $j$ in the year $\mathrm{t}$; this variable takes into account that free mobility does not coincide in time with EU accession in some cases. To take into account any potential specific characteristics that are particular to the UK, this variable is interacted with a UK dummy, both for migration into and out of the UK. The variable CU stands for a currency union, the variable EIA for an economic integration agreement and the variable FTA for a free trade agreement, as codified in Mario Larch's Regional Trade Agreements Database (Egger and Larch, 2008). As usual, these variables are lagged 5 years to allow for a delayed response of migration. ${ }^{10}$ In this database, the EU is codified jointly as a currency union and an economic integration agreement.

In the second step, following Anderson et al. (2018) and UNCTAD-WTO (2016) for trade, and Sirries (2017) for migration, we solve the system of equations that describe the conditional general equilibrium for trade and migration flows, taking into account the consequences of a change in bilateral trade or migration costs not only on the countries directly affected by the change, but also on third countries. Within this framework, the effects of a trade or migration policy change influence third countries through the general equilibrium multilateral resistance terms, while output and expenditure are assumed to remain unchanged. In the case of trade, we solve equation (1) to obtain the "complete matrix of bilateral trade costs", ${ }^{11}$ limiting our analysis to partial and conditional general equilibrium effects (see UNCTAD and WTO, 2016, for details), not estimating full general equilibrium effects in the case of trade because changes in population induced by changes in migration may render the methodology invalid. In the case of migration, we use the model of Anderson (2011) to obtain the bilateral migration frictions in the way described by Sirries (2017). We specify a relationship between bilateral migration frictions and various distance variables used in the literature, imposing the coefficients obtained for the variables of interest from the estimation in (2). We then use the predicted estimates of these bilateral migration frictions together with the equations characterising an equilibrium in the model of Anderson (2011) to solve for the complete matrix of bilateral migration flows, which are a function of the variables describing mobility within the EU and the various dummy variables that codify the type of trade agreement between countries.

In the third step, we define two alternative scenarios, with respect to our baseline of "no policy change" and solve the model. The first one is a "WTO scenario", in which the UK exits the EU without any formal agreement on trade or migration, therefore relying on nothing other than WTO rules. In the case of trade, we implement this hypothesis by forcing the EUUK dummy

10 Estimates are also robust to using four-year lags, akin to the case of trade.

11 We follow the Anderson and Yotov (2016) two-stage procedure, to avoid biases in estimating the alternative scenarios. 
equal to zero. In the case of migration, we compute the WTO scenario by setting the mobility variables EUmovUKin and EUmovUKout to zero and setting the variables representing the EU ( $C U$ and EIA) to zero. The second scenario is one in which the UK and the EU sign a FTA. Both for trade and migration, the FTA scenario is constructed by starting out from the WTO scenario and then switching the dummy variable FTA from zero to one for all pairs of countries that involve the UK and other EU members to simulate the effects of the UK belonging to an FTA. We then solve for equilibrium trade and migration based on the resulting bilateral friction parameters in the same way as described in the WTO scenario.

\section{Data}

In the case of trade, the data (bilateral exports) are from the UN Comtrade database. We include both international and intra-national trade flows, the latter being calculated as the difference between total manufacturing production and total manufacturing exports. Due to restrictions in intra-national data, we focus on the 1986-2006 time interval. As already said, we follow Anderson and Yotov (2016) in assuming that trade policy-related adjustment does not happen instantaneously, therefore using 4-year time intervals. Data are consistently available for 69 countries, among those 19 current EU members, ${ }^{12}$ other than the UK. EU and Euro membership has been coded following European Commission data. ${ }^{13}$ FTA data have been retrieved from Mario Larch's Regional Trade Agreements Database (Egger and Larch, 2008), which includes "all multilateral and bilateral trade agreements as notified to the World Trade Organization".

In the case of migration, migration flows are taken from the OECD International Migration database. The database covers the years 1997-2014. It contains bilateral migration flows between 206 origin countries and 35 destination countries. Data are reported in terms of gross flows.

12 Austria, Belgium, Bulgaria (which joined the EU in 2007, after the time interval of our trade database), Cyprus, Denmark, Finland, France, Germany, Greece, Hungary, Ireland, Italy, Malta, the Netherlands, Poland, Portugal, Romania (joined in 2007), Spain, Sweden.

13 Available at https://europa.eu/european-union/about-eu/countries_en\#tab-0-1 


\section{Results}

Results shown in this section have to be interpreted as medium to long-run effects, in a comparative static fashion, i.e. when all the factors that are presumed to affect trade and migration have materialised. ${ }^{14}$

The estimates for the Brexit effect on trade are presented in Figure $1 .{ }^{15}$ In the WTO scenario, bilateral trade flows between UK and the rest of the world are set to drop about 30\% in volume, an effect driven by setting to zero the EU-UK dummy, and slightly reinforced $(-0.2 \%)$ by the multilateral trade resistances taken into account in the model. The EU will also see a reduction in its bilateral trade flows driven by the same forces, but very moderate in relative size, with a decline of $2 \%$ approximately. Results for the Euro area are not appreciably different from those of the EU as a whole. The US and the rest of the world (RoW) are expected to see small increases in bilateral trade flows, well below $0.5 \%$. Brexit will also affect total world trade, which is set to drop close to $2 \%$.

In the FTA scenario, the Brexit effect on trade is small. In our trade regression, the FTA dummy has a positive and significant effect on trade flows, in line with the rest of the related literature (see i.a. Baier and Bergstrand, 2007). The presence of a trade agreement between the EU and the UK - assuming that the effect of this FTA is equal to the average effect of the FTAs included in the sample - lessens the reduction in bilateral trade flows to $-10 \%$ in volume, and to $-0,8 \%$ for the EU. Trade flows involving the US and the RoW would increase only very marginally (between +0.1 and $+0.2 \%$ )

The estimates for the effect of Brexit on migration are presented in Figure $2 .{ }^{16}$ In this case, estimates for the WTO scenario and the FTA scenario are similar. Indeed, in the migration regression, the FTA dummy is not statistically different from zero (see Appendix). This implies that when, in addition to the changes described for the WTO scenario, we switch the dummy variable FTA ${ }_{\mathrm{ijt}}$ from zero to one for all pairs of countries that involve the UK and other EU members, this does not produce any change in migration. The result that signing an FTA does not have a noticeable impact on migration differs from some previous results in the literature, such as Orefice (2015). However, Orefice (2015) does not consider the universe of free trade agreements, but preferential trade agreements only (i.e. non-reciprocal preferential schemes).

Therefore, in both the scenarios considered, Brexit is expected to have a strong impact on migration flows to the UK, which could fall by up to $25 \%$. Effects on migration are however opposite for the EU member states as recipients: they are expected to receive more inflows per year, mostly coming from other EU member states (+2\% approximately).

14 Unlike trade, yearly population growth forecasts are available from a range of international organisations (e.g. United Nations, OECD and European Commission) and short-run estimates are available upon request.

15 Results of the underlying estimations are presented in the Appendix (Table A.1).

16 Results of the underlying equation are presented in the Appendix (Table A.2). 
1 TRADE

trade flows (volume \% change w.r.t. baseline)

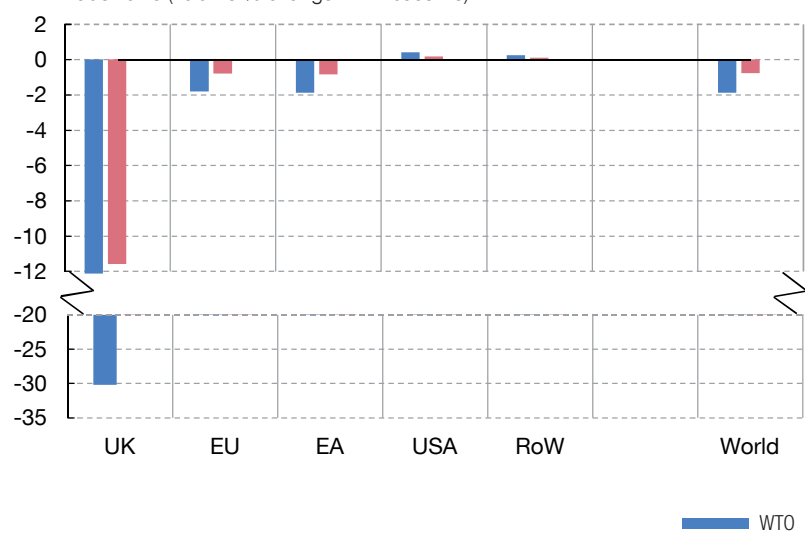

2 MIGRATION

migration flows (\% change w.r.t. baseline)

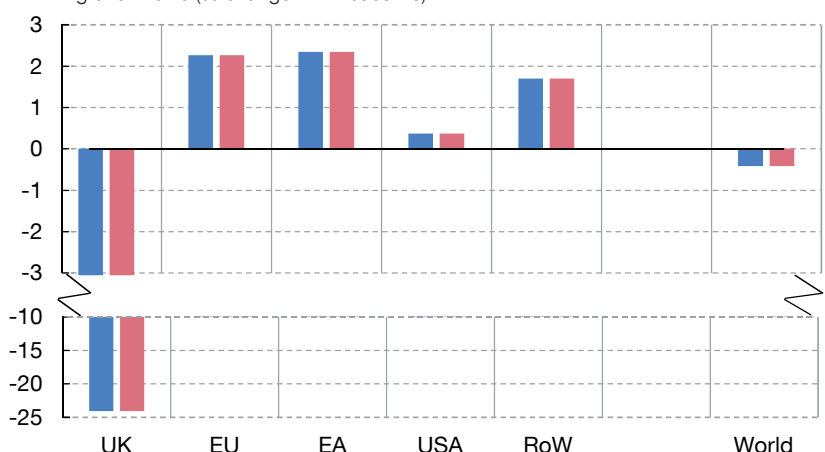

SOURCE: Prepared by authors.

NOTE: When aggregated at the supranational level, results are the weighted average of trade and population flows.

On the other hand, immigrants from EU countries, while going abroad, will prefer to choose alternative locations with respect to the UK. ${ }^{17}$

\section{Conclusions}

In this paper we estimate the effects of Brexit on trade and migration. To do so, we implement a structural gravity model. The quantitative analysis shows robust negative effects both on trade and migration flows for the UK owing to Brexit. Our results are in line with the literature both in terms of sign and size. When we consider the EU-27, the negative effects on aggregate trade flows are much more limited in size. An FTA agreement (which does not include free labour mobility) between the UK and the EU has the potential to reduce the negative effects on trade by a substantial amount but is not expected to have a significant effect on migration. As this analysis is conducted using aggregate data, we cannot rule out the possibility that trade for single products may be particularly hit due to a particular increase in tariffs or divergence in non-tariff measures.

17 In our analysis we have quantified the possibility that the large stock of EU citizens currently living in the UK or that of UK citizens living in EU countries may wish to relocate after Brexit. If that were to happen, then migration flows of these currently stationary populations may add to the migration flows calculated in this section. 
APPENDIX

TRADE PPML PANEL STRUCTURAL GRAVITY ESTIMATIONS

TABLE A.1

Trade regression results

\begin{tabular}{lc}
\hline EU & $0.3765^{\star \star \star}$ \\
& $(0.0518)$ \\
\hline EU_GB & $0.4599^{\star \star \star}$ \\
$(0.1354)$
\end{tabular}

NOTE: Dependent variable: bilateral export flows (including intra-national flows, see UNCTAD-WTO, 2016). Exporter-year, importer-year and pair fixed effect are included in the regression but not reported. Robust standard errors in parentheses; ${ }^{\star * \star} \mathrm{p}<0.01,{ }^{* \star} \mathrm{p}<0.05,{ }^{*} \mathrm{p}<0.1$.

MIGRATION PPML PANEL STRUCTURAL GRAVITY ESTIMATIONS

TABLE A.2

Migration regression results

\begin{tabular}{lc}
\hline EU & 0.0168 \\
& $(0.0909)$ \\
\hline EUmovUKin & $1.266^{\star \star \star}$ \\
& $(0.292)$ \\
\hline FTA & -0.0975 \\
& $(0.132)$ \\
\hline Economic Integration Agreement & -0.132 \\
& $(0.0922)$ \\
\hline Currency Union & $0.268^{\star \star \star}$ \\
\hline Observations & $(0.0740)$ \\
\hline R-squared & 0.144 \\
\hline
\end{tabular}

NOTE: Dependent variable: bilateral migration flows. Origin-time, destination-time and pair fixed effects are included in the regression but not reported. The regression also includes partial scope agreements (not reported) as an additional control. Robust standard errors in parentheses; ${ }^{\star \star \star} \mathrm{p}<0.01,{ }^{\star \star} \mathrm{p}<0.05,{ }^{*} \mathrm{p}<0.1$. 


\section{References}

ALVAREZ, R., and R. A. LOPEZ (2008). "Is Exporting a Source of Productivity Spillovers?", Review of World Economics, 144:723-749.

ANDERSON, J. (2011). "The Gravity Model", Annual Review in Economics, 3:133-160.

ANDERSON, J. E., and Y. YOTOV (2016). "Terms of trade and global efficiency effects of free trade agreements, 19902002", 99:279-298.

ANDERSON, J. E., and E. VAN WINCOOP (2003). "Gravity with gravitas: a solution to the border puzzle", American Economic Review, 93:170-92.

ANDERSON, J. E., M. LARCH and Y. YOTOV (2018). "Estimating General Equilibrium Trade Policy Effects: GE PPML", The World Economy, 41:2750-2782.

BAIER, S. L., and J. H. BERGSTRAND (2007). "Do free trade agreements actually increase members' international trade", Journal of International Economics, 71:72-95.

BALDWIN, R. E., and D. TAGLIONI (2006). "Gravity for Dummies and Dummies for Gravity Equations", NBER Working Paper 12516, September.

BANK OF ENGLAND (2018). "EU withdrawal scenarios and monetary and financial stability: A response to the House of Commons Treasury Committee".

BEINE, M., F. DOCQUIER and C. ÖZDEN (2011). "Diasporas", Journal of Development Economics, 95(1): 30-41.

BERTOLI, S., and J. FERNÁNDEZ-HUERTAS MORAGA (2013). "Multilateral resistance to migration", Journal of Development Economics, 102: 79-100.

BISCIARI, P. (2019). "A survey of the long-term impact of Brexit on the UK and the EU27 economies", National Bank of Belgium, Working Paper 366, forthcoming.

BUSCH B., and J. MATTHES (2016). Brexit - the economic impact: A meta-analysis, IW-Report, No. 10/2016.

CALIENDO L,. and F. PARRO (2015). "Estimates of the Trade and Welfare Effects of NAFTA", The Review of Economic Studies, 82: 1-44.

CARRÈRE, C. (2006). "Revisiting the effects of regional trade agreements on trade flows with proper specification of the gravity model', European Economic Review, 50:223-247.

CIPOLLINA, M., and L. SALVATICI (2010). "Reciprocal Trade Agreements in Gravity Models: A Meta-Analysis", Review of International Economics, 18:63-80.

CORTINOVIS, N., and F. VAN OORT (2018). "Between spilling over and boiling down: network-mediated spillovers, local knowledge base and productivity in European regions", Journal of Economic Geography, https://doi.org/10.1093/jeg/ lby058

CORTINOVIS, N., and J. TIMINI (2018). "Learning from exporters: establishment-level productivity spillovers in Colombia", mimeo. CUENCA GARCÍA, E., M. NAVARRO PABSDORF and E. GÓMEZ HERRERA (2013). "The gravity model analysis: an application on MERCOSUR trade flows", Journal of Economic Policy Reform, 16:336-348.

DE BROMHEAD, A., A. FERNIHOUGH, M. LAMPE and K. H. O'ROURKE (2017). "When Britain turned inward: Protection and the shift towards Empire in Interwar Britain", NBER Working Paper No. 23164, March.

DHINGRA, S., H. HUANG, G. OTTAVIANO, J. PAULO PESSOA, T. SAMPSON and J. VAN REENEN (2017). "The costs and benefits of leaving the EU: trade effects", Economic Policy, 32:651-705.

EGGER, H. PETER and M. LARCH (2008). Interdependent Preferential Trade Agreement Memberships: An Empirical Analysis, Journal of International Economics, 76: 384-399.

EUR-LEX (2018). "Internal Market", available at https://eur-lex.europa.eu/homepage.html, last access January 2019.

FEENSTRA, R. C. (2016), "Gains from trade under monopolistic competition", Pacific Economic Review, 21:35-44.

FIGUEIREDO, E., L. R. LIMA, and G. OREFICE (2016). "Migration and regional trade agreements: A (new) gravity estimation", Review of international economics, 24(1): 99-125.

FRANKEL (1997). Regional Trading Blocs in the World Economic System, Washington DC: Institute for International Economics.

FRANKEL, J. A., and A. K. ROSE (2005). "Is Trade Good or Bad for the Environment? Sorting Out the Causality", Review of Economics and Statistics, 87:85-91.

GLICK, R. (2017). "Currency Unions and Regional Trade Agreements: EMU and EU Effects on Trade", Comparative Economic Studies, 59:194-209

GLICK, R., and A. K. ROSE (2016). "Currency unions and trade: A post-EMU reassessment”, European Economic Review, 87:78-91.

GROGGER, J., and G. H. HANSON (2011). "Income maximization and the selection and sorting of international migrants", Journal of Development Economics, 95(1): 42-57. 
GYLFASON, T., I. MARTINEZ-ZARZOSO and P. M. WIJKMAN (2015). "Free Trade Agreements, Institutions and the Exports of Eastern Partnership Countries", Journal of Common Market Studies, 53:1214-1229.

HEAD, K., and T. MAYER (2014). "Gravity Equations: Workhorse, Toolkit, and Cookbook", in G. GOPINATH, E. HELPMAN and K. ROGOFF (eds), Handbook of International Economics, Elsevier: 131-195.

HM TREASURY (2016). "The long-term economic impact of EU membership and the alternatives", April.

IMF (2018). “United Kingdom - Selected Issues”, IMF Staff Country Report n. 18/317, November.

ISLAM et al. (2014). "How effective is the Free Trade Agreement in South Asia? An empirical investigation", International Review of Applied Economics, 28:611-627.

KIERZENKOWSKI, R., N. PAIN, E. RUSTICELLI and S. ZWART (2016). "The economic consequences of Brexit: a taxing decision", OECD Economic Policy Paper n.16, April.

MAYER, T., V. VICARD and S. ZIGNAGO (2019). "The Cost of Non-Europe, Revisited”, Economic Policy, forthcoming. MION, et al. (2016). "The Diffusion of Knowledge via Managers' Mobility”, CESIFO Working Paper No.6256, December.

MULABDIC, A., A. OSNAGO and M. RUTA (2017). "Deep Integration and UK-EU Trade Relations”, Policy Research Working Paper 7947, World Bank.

NOWAK-LEHMANN, D. F., and I. MARTINEZ-ZARZOSO (2005). "MERCOSUR-EUROPEAN UNION TRADE: How Important is EU Trade Liberalization for MERCOSUR's Exports?", The International Trade Journal, 19:31-66.

OREFICE, G. (2015). "International migration and trade agreements: The new role of PTAs", Canadian Journal of Economics / Revue canadienne d'economique, 48: 310-334

ORTEGA, F., and G. PERI (2013). "The effect of income and immigration policies on international migration", Migration Studies, 1(1): 47-74.

OTTAVIANO, G. (2014). "European Integration and the Gains from Trade", in H. Badinger and V. Nitsch, Handbook of the Economics of European Integration, Routledge.

PARRA, M. D., I. MARTINEZ-ZARZOSO and C. SUAREZ-BURGUET (2016). "The impact of FTAs on MENA trade in agricultural and industrial products", Applied Economics, 48:2341-2353.

PISANI, M., and F. VERGARA CAFFARELLI (2018). "What will Brexit mean for the British and euro-area economies? A model-based assessment of trade regimes", Banca d'Italia Working Papers n.1163, January.

ROMALIS, J. (2007). "NAFTA's and CUSFTA's Impact on International Trade", The Review of Economics and Statistics, 89:416-435

ROSE, A. K. (2000). "One money, one market: the effect of common currencies on trade", Economic Policy, 15:7-45.

SIRRIES S. (2017). "Comparative Statics Quantification of Structural Migration Gravity Models”, mimeo.

THE HOUSE OF COMMONS TREASURY COMMITTEE (2018). The UK's economic relationship with the European Union: The Government's and Bank of England's Withdrawal Agreement analyses. Twenty-Fifth Report of Session 2017-1

TIMINI, J. (2018). "Currency unions and heterogeneous trade effects: the case of the Latin Monetary Union", European Review of Economic History, 22:322-348.

TINBERGEN, J. (1962). "An Analysis of World Trade Flows," in J. Tinbergen (ed.) Shaping the World Economy, New York: Twentieth Century Fund.

UNCTAD and WTO (2016). "An Advanced Guide to Trade Policy Analysis: The Structural Gravity Model", Geneva: WTO.

YANG, S., and I. MARTINEZ-ZARZOSO (2014). "A panel data analysis of trade creation and trade diversion effects: The case of ASEAN-China Free Trade Area", China Economic Review, 29:138-151.

YOTOV, Y. (2012). "A simple solution to the distance puzzle in international trade", Economics Letters, 117:794-798.

$\mathrm{YU}$, et al. (2014). "The impact of the ACFTA on ASEAN-PRC trade: estimates based on extended gravity model for component trade", Applied Economics, 46:2251-2263.

YU, M. (2010). "Trade, democracy, and the gravity equation", Journal of Development Economics, 91:289-300. 


\title{
BANCO DE ESPAÑA PUBLICATIONS
}

\author{
OCCASIONAL PAPERS
}

1401 JOSÉ MARÍA SERENA and EVA VALDEOLIVAS: Integración financiera y modelos de financiación de los bancos globales.

1402 ANTONIO MONTESINOS, JAVIER J. PÉREZ and ROBERTO RAMOS: El empleo de las Administraciones Públicas en España: caracterización y evolución durante la crisis.

1403 SAMUEL HURTADO, PABLO MANZANO, EVA ORTEGA and ALBERTO URTASUN: Update and re-estimation of the Quarterly Model of Banco de España (MTBE).

1404 JUAN CARLOS BERGANZA, IGNACIO HERNANDO and JAVIER VALLÉS: Los desafíos para la política monetaria en las economías avanzadas tras la Gran Recesión.

1405 FERNANDO LÓPEZ VICENTE and JOSÉ MARÍA SERENA GARRALDA: Macroeconomic policy in Brazil: inflation targeting, public debt structure and credit policies.

1406 PABLO HERNÁNDEZ DE COS and DAVID LÓPEZ RODRÍGUEZ: Tax structure and revenue-raising capacity in Spain: A comparative analysis with the UE. (There is a Spanish version of this edition with the same number).

1407 OLYMPIA BOVER, ENRIQUE CORONADO and PILAR VELILLA: The Spanish survey of household finances (EFF): description and methods of the 2011 wave.

1501 MAR DELGADO TÉLLEZ, PABLO HERNÁNDEZ DE COS, SAMUEL HURTADO and JAVIER J. PÉREZ: Extraordinary mechanisms for payment of General Government suppliers in Spain. (There is a Spanish version of this edition with the same number).

1502 JOSÉ MANUEL MONTERO y ANA REGIL: La tasa de actividad en España: resistencia cíclica, determinantes y perspectivas futuras.

1503 MARIO IZQUIERDO and JUAN FRANCISCO JIMENO: Employment, wage and price reactions to the crisis in Spain: Firm-level evidence from the WDN survey.

1504 MARÍA DE LOS LLANOS MATEA: La demanda potencial de vivienda principal.

1601 JESÚS SAURINA and FRANCISCO JAVIER MENCÍA: Macroprudential policy: objectives, instruments and indicators. (There is a Spanish version of this edition with the same number).

1602 LUIS MOLINA, ESTHER LÓPEZ y ENRIQUE ALBEROLA: El posicionamiento exterior de la economía española.

1603 PILAR CUADRADO and ENRIQUE MORAL-BENITO: Potential growth of the Spanish economy. (There is a Spanish version of this edition with the same number).

1604 HENRIQUE S. BASSO and JAMES COSTAIN: Macroprudential theory: advances and challenges.

1605 PABLO HERNÁNDEZ DE COS, AITOR LACUESTA and ENRIQUE MORAL-BENITO: An exploration of real-time revisions of output gap estimates across European countries.

1606 PABLO HERNÁNDEZ DE COS, SAMUEL HURTADO, FRANCISCO MARTÍ and JAVIER J. PÉREZ: Public finances and inflation: the case of Spain.

1607 JAVIER J. PÉREZ, MARIE AOURIRI, MARÍA M. CAMPOS, DMITRIJ CELOV, DOMENICO DEPALO, EVANGELIA PAPAPETROU, JURGA PESLIAKAITÉ, ROBERTO RAMOS and MARTA RODRÍGUEZ-VIVES: The fiscal and macroeconomic effects of government wages and employment reform.

1608 JUAN CARLOS BERGANZA, PEDRO DEL RÍO and FRUCTUOSO BORRALLO: Determinants and implications of low global inflation rates.

1701 PABLO HERNÁNDEZ DE COS, JUAN FRANCISCO JIMENO and ROBERTO RAMOS: The Spanish public pension system: current situation, challenges and reform alternatives. (There is a Spanish version of this edition with the same number).

1702 EDUARDO BANDRÉS, MARÍA DOLORES GADEA-RIVAS and ANA GÓMEZ-LOSCOS: Regional business cycles across Europe.

1703 LUIS J. ÁLVAREZ and ISABEL SÁNCHEZ: A suite of inflation forecasting models.

1704 MARIO IZQUIERDO, JUAN FRANCISCO JIMENO, THEODORA KOSMA, ANA LAMO, STEPHEN MILLARD, TAIRI RÕÕM and ELIANA VIVIANO: Labour market adjustment in Europe during the crisis: microeconomic evidence from the Wage Dynamics Network survey.

1705 ÁNGEL LUIS GÓMEZ and M. ${ }^{a}$ DEL CARMEN SÁNCHEZ: Indicadores para el seguimiento y previsión de la inversión en construcción.

1706 DANILO LEIVA-LEON: Monitoring the Spanish Economy through the Lenses of Structural Bayesian VARs.

1707 OLYMPIA BOVER, JOSÉ MARÍA CASADO, ESTEBAN GARCÍA-MIRALLES, JOSÉ MARÍA LABEAGA and ROBERTO RAMOS: Microsimulation tools for the evaluation of fiscal policy reforms at the Banco de España.

1708 VICENTE SALAS, LUCIO SAN JUAN and JAVIER VALLÉS: The financial and real performance of non-financial corporations in the euro area: 1999-2015. 
1709 ANA ARENCIBIA PAREJA, SAMUEL HURTADO, MERCEDES DE LUIS LÓPEZ and EVA ORTEGA: New version of the Quarterly Model of Banco de España (MTBE).

1801 ANA ARENCIBIA PAREJA, ANA GÓMEZ LOSCOS, MERCEDES DE LUIS LÓPEZ and GABRIEL PÉREZ QUIRÓS: A short-term forecasting model for the Spanish economy: GDP and its demand components.

1802 MIGUEL ALMUNIA, DAVID LÓPEZ-RODRÍGUEZ and ENRIQUE MORAL-BENITO: Evaluating the macro-representativeness of a firm-level database: an application for the Spanish economy.

1803 PABLO HERNÁNDEZ DE COS, DAVID LÓPEZ RODRÍGUEZ and JAVIER J. PÉREZ: The challenges of public deleveraging. (There is a Spanish version of this edition with the same number).

1804 OLYMPIA BOVER, LAURA CRESPO, CARLOS GENTO and ISMAEL MORENO: The Spanish Survey of Household Finances (EFF): description and methods of the 2014 wave.

1805 ENRIQUE MORAL-BENITO: The microeconomic origins of the Spanish boom.

1806 BRINDUSA ANGHEL, HENRIQUE BASSO, OLYMPIA BOVER, JOSÉ MARÍA CASADO, LAURA HOSPIDO, MARIO IZQUIERDO, IVAN A. KATARYNIUK, AITOR LACUESTA, JOSÉ MANUEL MONTERO and ELENA VOZMEDIANO: Income, consumption and wealth inequality in Spain. (There is a Spanish version of this edition with the same number).

1807 MAR DELGADO-TÉLLEZ and JAVIER J. PÉREZ: Institutional and economic determinants of regional public debt in Spain.

1808 CHENXU FU and ENRIQUE MORAL-BENITO: The evolution of Spanish total factor productivity since the Global Financial Crisis.

1809 CONCHA ARTOLA, ALEJANDRO FIORITO, MARÍA GIL, JAVIER J. PÉREZ, ALBERTO URTASUN and DIEGO VILA: Monitoring the Spanish economy from a regional perspective: main elements of analysis.

1810 DAVID LÓPEZ-RODRÍGUEZ and CRISTINA GARCÍA CIRIA: Estructura impositiva de España en el contexto de la Unión Europea.

1811 JORGE MARTÍNEZ: Previsión de la carga de intereses de las Administraciones Públicas.

1901 CARLOS CONESA: Bitcoin: a solution for payment systems or a solution in search of a problem? (There is a Spanish version of this edition with the same number).

1902 AITOR LACUESTA, MARIO IZQUIERDO and SERGIO PUENTE: An analysis of the impact of the rise in the national minimum wage in 2017 on the probability of job loss. (There is a Spanish version of this edition with the same number).

1903 EDUARDO GUTIÉRREZ CHACÓN and CÉSAR MARTÍN MACHUCA: Exporting Spanish firms. Stylized facts and trends.

1904 MARÍA GIL, DANILO LEIVA-LEON, JAVIER J. PÉREZ and ALBERTO URTASUN: An application of dynamic factor models to nowcast regional economic activity in Spain.

1905 JUAN LUIS VEGA (COORD.): Brexit: current situation and outlook.

1906 JORGE E. GALÁN: Measuring credit-to-GDP gaps. The Hodrick-Prescott filter revisited.

1907 VÍCTOR GONZÁLEZ-DÍEZ and ENRIQUE MORAL-BENITO: The process of structural change in the Spanish economy from a historical standpoint. (There is a Spanish version of this edition with the same number).

1908 PANA ALVES, DANIEL DEJUÁN and LAURENT MAURIN: Can survey-based information help assess investment gaps in the EU?

1909 OLYMPIA BOVER, LAURA HOSPIDO and ERNESTO VILLANUEVA: The Survey of Financial Competences (ECF): description and methods of the 2016 wave.

1910 LUIS JULIÁN ÁLVAREZ: El índice de precios de consumo: usos y posibles vías de mejora.

1911 ANTOINE BERTHOU, ÁNGEL ESTRADA, SOPHIE HAINCOURT, ALEXANDER KADOW, MORITZ A. ROTH and MARIE-ELISABETH DE LA SERVE: Assessing the macroeconomic impact of Brexit through trade and migration channels.

1912 RODOLFO CAMPOS and JACOPO TIMINI: An estimation of the effects of Brexit on trade and migration.

\section{BANCODEESPAÑA} Eurosistema
Unidad de Servicios Auxiliares

Alcalá, 48 - 28014 Madrid

E-mail: publicaciones@bde.es www.bde.es 